\title{
Government Regulation, Technology and Development of SME-s
}

- Case of Albania

PhD Cand. Sorina Koti

University "Fan S. Noli" Korce-Albania

sorinakoti@gmail.com

Dr. Klaudeta Merollari

University "Fan S. Noli" Korce-Albania

klaudetamerollari@yahoo. it

\begin{abstract}
The aim of the paper is to analyze the factors that determine business growth and the impact on the GDP of the country. The paper analyses Albania, as one of the countries in the South East Europe. Albania is still passing through a transition period at all levels, economic and political. Albania has made serious steps in the development of the state of law, of the financial system and it is working on the achievements of goals, such as: becoming an EU member, stabilization of the fiscal and monetary policies, stability of prices, fighting against corruption, incentives for private investments, reduction of business's taxes etc. The achievement of these goals will bring more motivation and incentives for growth, an increase in domestic and foreign direct investments. The government of Albania is still working on the future strategies that will bring Albania near to the European countries. The partial achievement of the above goals has created a positive environment, but still there is enough room for change and stabilization. The Albanian governments have improved the business climate, in order to create easier methods in the way of doing business, by attracting more foreign investors and creating a positive climate. Albania has experienced an increase of interest from foreign companies, which have invested in the main fields of economic such as: banking, energy, telecommunication, gas-oil, supermarkets, construction etc. However, some fiscal policies have changed during the last three years, which has caused a tightening of credit, investment, growth and income. Nowadays, Albania is not in a good position compare to neighborhood countries and it is facing recession problems that need immediate solution to overcome the crisis.
\end{abstract}

Keywords: entrepreneurship trainings, strategies, policies on SME-s, technology, regulation

\section{Introduction and Economic Sectors}

The sustainability of economic growth during the last years, which is reflected in the sustainability of macroeconomic indicators, cannot be assured for the coming years, if the government policies and programs do not provide a speedy development of private sector, especially the SME's, the growth of exports and investments, etc. All these coincide with the need to raise the productivity and the competitiveness of the Albanian economy with further economic opening of the country and continuous improvement of legal framework, which supports the integration process of the country. The speedy growth of the businesses and investments' development climate, the increase of competitiveness of SMEs in regional and global market through development of technology and information, may bring a reduction of administrative barriers and creation of business facilities. 
SMEs development and their contribution in the long-term economic stability depend on their size and structure, which being under well-developed market conditions allows them to have flexibility and abilities suitable for tough competition conditions. Modern economies operate as a complex network of firms where the competitive position of a firm depends partly on the efficiency of its suppliers. Thus, SMEs competition affects the competitive position of the economy. As the high costs of transactions are one of the main barriers of their development, their reduction would influence the SMEs expansion and would especially encourage the expansion of micro-enterprises.

Development of SMEs sector is considered as the most efficient means for the transition economies, which generates a sustainable economic growth, employment and poverty reduction. During the last years, Albania has been through an economic decline, but still in positive level 1. 5-2\%, which was one of the best positions in the region. There is no doubt that the SMEs sector has an indisputable contribution of this process. According to the evaluations, the contribution of SMEs sector contributes at $64 \%$ of GDP and $66 \%$ of employment in private sector. According to the economic sectors, the distribution of active private businesses is trading $(49 \%)$, services $(24 \%)$, industry $(11 \%)$ and transport (10). Furthermore, the SME sector had a constant development during the years of transition. Furthermore, the graph below shows the contribution of each sector in the employment of the working force. It should be said that in the agriculture sector most of the businesses are small ones or family businesses and it is supposed that all people that are able to work are employed. Meanwhile, it is difficult to employ all the working force in the urban areas, because the economic system is not capable to develop working places.

\section{Fig. 1 Employment by sector}

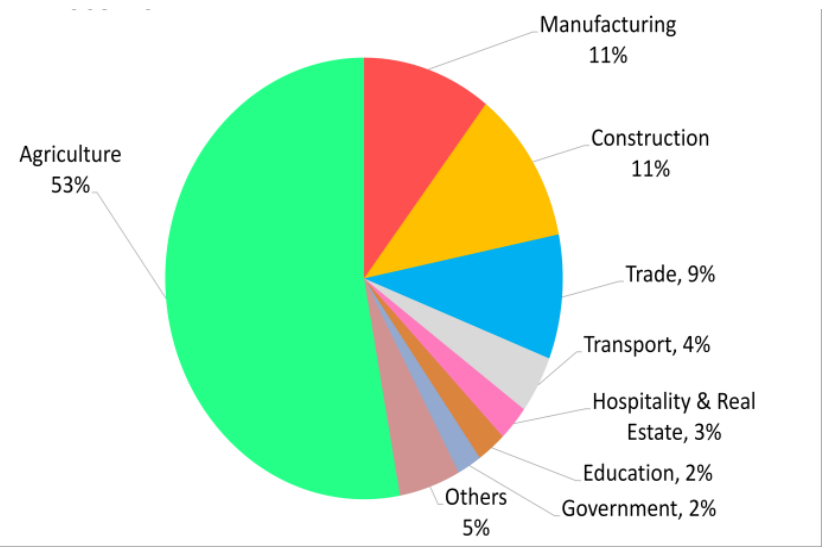

Source: MF, 2015

Hence, after agriculture, we see that construction and manufacturing are the two main sectors in the Albanian economy. Since the beginning of the global crisis, construction was the first sector that was hit first, because people were afraid to expend their savings and remittances were reduced drastically. While, the manufacturing sector is working at $70 \%$ capacity, because of the reduced level of foreign demand for exports and a reduction of internal demand for goods. The trade deficit is still negative, by experiencing a decline both in exports and imports as well.

\section{General view: situation and problems in the SMEs sector}

The sustainable macroeconomic and financial environment has created suitable conditions for credit expansion during the years 2005-2009. However, we need to take in consideration the last financial crisis and the effects of it. According to the Bank of Albania, since the beginning of the economic crisis in 2008, there has been a tight credit policy for private sector and for individuals as well. Banks tightened further the credit procedures, in order to protect their stability and to increase the credit/deposit ratio. Some of the most important features are listed below: 
- At the end of December 2015, the credit portfolio of banking system decreased by $16 \%$ compared to the previous year; while the credit to the private sector changed by $14 \%$ compared to the same period last year.

- $66.6 \%$ of credit portfolio is dominated from the business credits and $33.4 \%$ by individual credit.

- About $40 \%$ of loans given to business are used for buying cars and equipment.

Nevertheless, even the Bank of Albania has reduced the interest rate, in order to stimulate crediting the demand for credit from the private sector remains low, because of instability in the political-economic conditions

\section{1 Competitiveness of the Albanian economy}

Competitiveness of the Albanian economy is estimated according to the Index of Competitiveness Growth 2015-2016 (Report of Global Competitiveness 2015-2016 of the World Economic Forum). The index of economic competitiveness is estimated to be 3.9 from 7, which is the maximum. Albania takes the 93th position in the world ranking from the 97th place where was classified the previous year. It is classified the last country in the region concerning the economic competitiveness.

Tab. 1 The Global Competitiveness Index 2015-2016

\begin{tabular}{|l|l|l|l|l|l|l|}
\hline & \multicolumn{2}{|l|}{$\begin{array}{l}\text { Innovation } \\
\text { sophistication factors }\end{array}$} & \multicolumn{2}{l|}{ Business sophistication } & \multicolumn{2}{l|}{ Innovation } \\
& Rank & score & Rank & Score & Rank & Score \\
\hline Albania & 115 & 3.21 & 95 & 3.65 & 118 & 2.76 \\
\hline
\end{tabular}

Source: The Global Competitiveness Index, 2015-2016

Although, there is an improvement of free market competition, but there is a lot to be done in institutional strengthening, where the efficient functioning of Competition Authority is important, as well as, fostering the structures of market supervision and inspections of market control, more specifically directories of standardization, metrology and calibration, etc. Moreover, Albania lacks development in technology and innovation, because of the minimum funds from the government budget.

Government regulation and sometimes overregulation can lead to a high restriction of business operations, such as:

higher costs because of high bureaucratic procedures for new licenses and investment projects;

high costs of legal documentations and time spending;

high costs because of administration pressure through the increase level of controls;

reduction of selling opportunities and limits the market operations;

reduction number of licenses and operators, by causing oligopoly situations;

more corruptive pressure from government employees;

higher costs through the increase of taxes for enterprises and consumers;

controlling and monitoring all the institutions (dependent and independent institutions from government), by censuring their managerial and financial autonomy; 
high fiscal burns from the increase of electricity price, oil price, raw materials, customs services' etc.

Furthermore, according to Doing Business (2016) the table below gives the ranking of Albania based on the performance of key topics for the years 2015 and 2016.

Tab. 2: Key Topics and Albania ranking

\begin{tabular}{|c|c|c|c|}
\hline Topics & $\begin{array}{l}\text { DB } 2016 \\
\text { Rank }\end{array}$ & DB 2015 Rank & Change in Rank \\
\hline Starting a Business & 58 & 54 & -4 \\
\hline $\begin{array}{l}\text { Dealing with Construction } \\
\text { Permits }\end{array}$ & 189 & 122 & -67 \\
\hline Getting Electricity & 162 & 159 & -3 \\
\hline Registering Property & 107 & 104 & +3 \\
\hline Getting Credit & 42 & 36 & -6 \\
\hline Protecting Minority Investors & 8 & 18 & 10 \\
\hline Paying Taxes & 142 & 130 & -12 \\
\hline Trading Across Borders & 37 & 37 & No change \\
\hline Enforcing Contracts & 96 & 96 & No change \\
\hline Resolving Insolvency & 42 & 40 & -2 \\
\hline
\end{tabular}

Source: DB, WB database, 2016

From the above figures, we can say that Albania has moved downward for these keys: starting a business, dealing with construction permits, getting electricity, registering property, getting credit, paying taxes and resolving insolvency. All these backwards come as a result of government hyper regulations; increase of bureaucracy; change of tax system from proportional to progressive tax; decrease of income, trade, consumption and blocking the building permits. If, we compare previous years of Albania, we can analyze that Albania has made paying taxes more costly, because the government changed the corporate tax rate from $10 \%$ to $15 \%$ and. Moreover, the fiscal burn is higher than the other countries in the region, by causing a decline in the competitiveness and attraction of foreign direct investments. Another problem is the construction sector, which is faced with a suspension of building permits by the government. While, on the other hand, Albania has made positive steps toward the registration of new businesses by lowering the fees and electronically registering them in one day. 
The tables below will show specifically most important key topics with a comparison of Albania with Europe and OECD high income countries.

\section{Key factor no. 1: Starting a Business}

\begin{tabular}{|l|l|l|l|}
\hline Indicator & Albania & Europe and Central Asia & OECD high income \\
\hline Procedures (number) & 6 & 4.7 & 4.7 \\
\hline Time (days) & 5.5 & 10 & 8.3 \\
\hline $\begin{array}{l}\text { Cost (\%of income per } \\
\text { capita) }\end{array}$ & 10.4 & 4.8 & 3.2 \\
\hline
\end{tabular}

In relation to these indicators, Albania is better for the time consumed to open a business, but it is much more costly (2-3 times more expensive) and it has more procedures than European and OECD countries. These indicate the high cost of operating in Albania.

\section{Key factor no. 2 Getting Electricity}

\begin{tabular}{|l|l|l|l|}
\hline Indicator & Albania & Europe and Central Asia & OECD high income \\
\hline Procedures (number) & 6 & 5.7 & 4.8 \\
\hline Time (days) & 177 & 118.5 & 77.7 \\
\hline $\begin{array}{l}\text { Cost (\%of income per } \\
\text { capita) }\end{array}$ & 491 & 440.2 & 65.1 \\
\hline
\end{tabular}

Again, the time consuming in Albania is much higher than in the other countries. The cost to get electricity is higher but almost the same as in Europe and Central Asia, while in comparison to OECD countries if extremely high. Albania has a very high electricity price even it has hydro centrals and plenty of water sources. The malfunction of the electricity system causes problem with the quantity and quality of electricity. Furthermore, because of not sufficient produced electricity capacities, Albania imports electricity from other countries, which increases the cost of it. Albania has all the needed sources, but it has serious problem with the production and management capacities.

\section{Key factor no. 3 Registering Property}

\begin{tabular}{|l|l|l|l|}
\hline Indicator & Albania & Europe and Central Asia & OECD high income \\
\hline Procedures (number) & 6 & 5.4 & 4.7 \\
\hline Time (days) & 22 & 22 & 21.8 \\
\hline $\begin{array}{l}\text { Cost (\%of income per } \\
\text { capita) }\end{array}$ & 10.2 & 2.6 & 4.2 \\
\hline
\end{tabular}

In the above table, again we can state that cost is the main problem in Albania. Because of high bureaucratic procedures, the cost for almost all government services is very high.

\section{Key factor no. 7 Paying Taxes}

\begin{tabular}{|l|l|l|l|}
\hline Indicator & Albania & Europe and Central Asia & OECD high income \\
\hline $\begin{array}{l}\text { Payments (number per } \\
\text { Year) }\end{array}$ & 34 & 19.2 & 11.1 \\
\hline Time (hours per year) & 357 & 232.7 & 176.6 \\
\hline $\begin{array}{l}\text { Total Tax Rate (\% of } \\
\text { Profit) }\end{array}$ & 36.5 & 34.8 & 41.8 \\
\hline Profit Tax (\% of profit) & 14.1 & 10.8 & 14.9 \\
\hline \multicolumn{2}{|l}{32} \\
\hline
\end{tabular}




\begin{tabular}{|l|l|l|l|}
\hline $\begin{array}{l}\text { Labor Tax and } \\
\text { contributions (\% of profit) }\end{array}$ & 18.8 & 20.4 & 24.1 \\
\hline Other taxes (\% of profit) & 3.6 & 3.1 & 1.7 \\
\hline
\end{tabular}

The tax procedures have changed during the last years. There is a reduction in the number of payments and time consumed per year, but still Albania remains with the highest procedure number and time spent for paying taxes compare to the other countries. Albania has made serious steps in the digitalization of paying taxes and online services, but still there is a lot to do toward corruption of administration staff and government regulation.

\section{Key factor no. 8 Trading Across Borders}

\begin{tabular}{|l|l|l|l|}
\hline Indicator & Albania & Europe and Central Asia & OECD high income \\
\hline Time to export (hours) & 18 & 28 & 15 \\
\hline Cost to export (USD) & 181 & 219 & 160 \\
\hline Time to import & 9 & 23 & 9 \\
\hline Cost to import (USD) & 101 & 202 & 123 \\
\hline
\end{tabular}

Source: DB, WB database, 2016

The last one, if we analyze the above data, we can state that Albania has approximately the same data as OECD data and it is one of the big achievements of the government. Trade is become easier, because of the implementation of an electronic risk-based inspection system. While the figure below makes a comparison of the key indicators between the year 2008 and 2014.

Fig. 2 Albania Distance to Frontier Change along Doing Business Categories 2008-2014

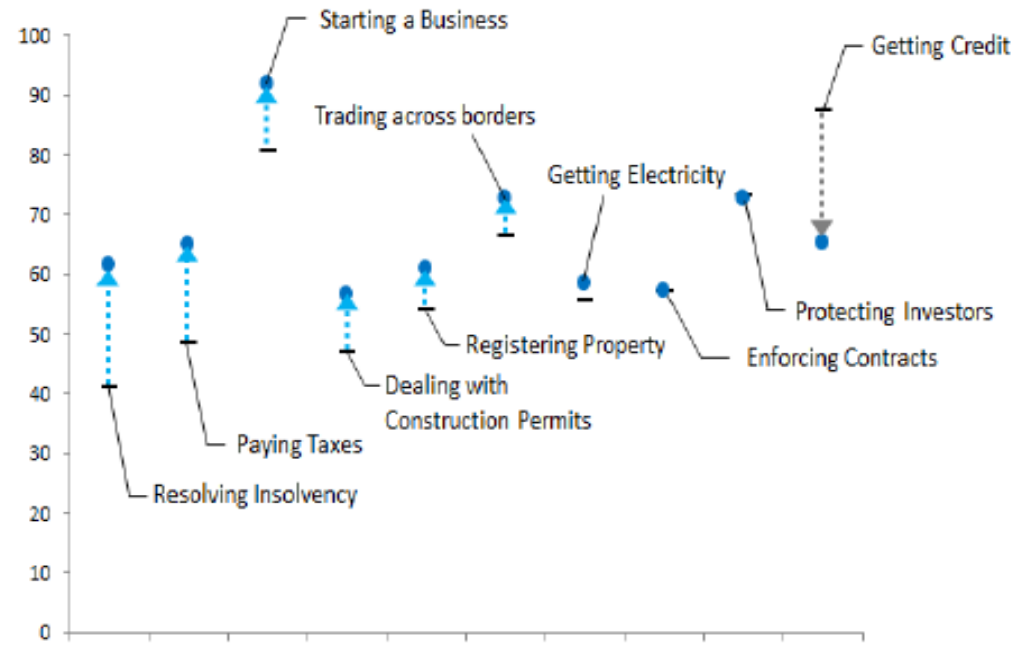

Source: WB, 2015 


\section{2 Informality in economy}

Informality in the Albanian economy is considered high and according to the evaluations from the Institution of statistics, it includes around 28-30 of GDP Level. Reduction of the informal economy is part of programs and reforms undertaken from the government. The inter-ministerial group for the informal economy has revised the action plan "For reducing the informal economy", approved by a decision of the Council of Ministers Nr. 246, date 21. 04. 2005. It has been prepared the newmiddle-term action plan for reducing the informal economy, where the forecasted measures aim to avoid the fiscal evasion concerning taxes, social insurances and reducing Cash in economy. The use of cash register will help in the reduction process of informality. Larger use of internet, specifically in the public administration is an important factor in reducing corruption and abuses concerning businesses. According to Transparency International (2015), Albania has 33 points from 100 and it is ranked the $110^{\text {th }}$ from 175 countries. Albania has the lowest performance in the South East Europe, with a high corruption level in the public sector. It is an urge to stop the fiscal evasion and corruption.

Fig. 3 Corruption Perception Indicators

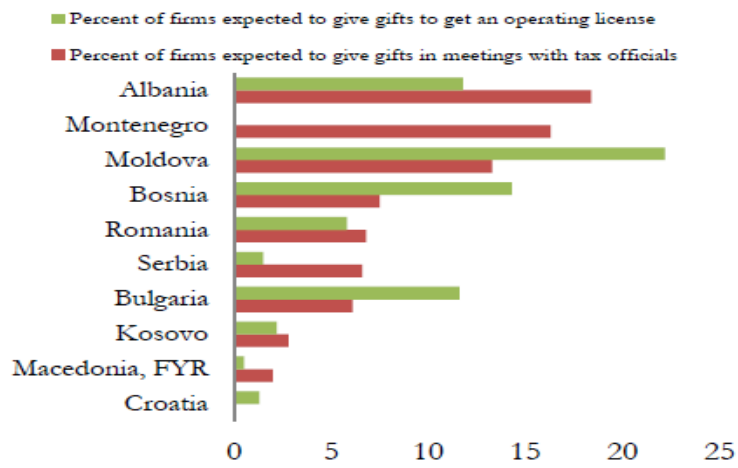

Source: EBRD, WB, 2016

175=worst)

\section{3 Policies in taxes and tariffs}

During 2006-2013 there have been undertaken a series of liberal policies, concerning taxes, in order to facilitate the fiscal burden on businesses and specifically:

Reduction of tax revenue from $23 \%$ to $10 \%$.

Reduction of simplified revenue tax for small businesses from 3. $5 \%$ to $1.5 \%$ and reducing about $50 \%$ the local tax on small businesses.

Removing the value added tax on books for the publishing house.

Removing the value added tax on advertisement.

However, the new government changed the fiscal structure from proportional tax to progressive tax system.

- From the January 2014 , the tax revenue and tax on source became $15 \%$, by facing an increase of $50 \%$.

- The value added for books was set again.

-The value added for university studies. 
- The local taxes has been increased by $30 \%$ by causing an economical stuck

Hence, this change brought many problems to businesses and foreign investors. Some of them left Albania and chose to operate in another Balkan country. Although, it is necessary to make some revisions and changes in the tax system, especially in implementing and controlling the legal framework. This gap in implementation and the lack of capacities in tax services demands more and more steps, which need to be undertaken in the tax administration.

\section{4 Procedures entering a business}

The Albanian governments initiated reforms aimed firstly to reduce the time a business needs to prepare documents, secondly cost reduction, thirdly increasing the business accountability on its own declarations and government institutions in their verification. Regarding the regulatory reform, the legal term for registering a business in the Court is shortened, from 30 days to 8 days (after the Law on "Commercial Registry". Furthermore, the compilation of the commercial registry in electronic form is under way, by creating a database containing all the companies operating in Albania, improving the recording procedures. All these reforms will reduce the time to register a business. The table below shows the ranking of Albania over some years in "Ease of Doing Business". As it is seen, Albania has made serious steps in the ease of doing business, but still there are a lot of obstacles to work the opening business.

Fig. 5 Albania ranking in "Ease of Doing Business"

\begin{tabular}{lcccccccccc}
\hline Year & 2006 & 2007 & 2008 & 2009 & 2010 & 2011 & 2012 & 2013 & 2014 & 2015 \\
Ranking & 117 & 120 & 136 & 86 & 82 & 82 & 82 & 85 & 108 & 68 \\
\hline
\end{tabular}

Source: DB, WB Database, 2015

\section{5 Financing schemes}

In order to improve the financing climate of SME-s in the course of years, there are taken several measures that deal mainly with the

Introduction of the credit schemes for the SMEs. The assurance funds in Albania have been applied through some special projects, in supporting the SMEs categories and not involving the best part of them. However, the SMEs, especially the new ones, face many difficulties in getting a bank loan and the cost is very high. Conditions that banks claim from businesses are not favorable and more precisely, the required collateral is in high levels from $140 \%-170 \%$ of the loan. On the other hand, the bank interest rates are very high, in cases when credit is requested for investments on fix assets, for $e$ mid-term period.

Fig. 6 Business and consumers credit (ALL and foreign currency; short-term, medium-term and long-term)

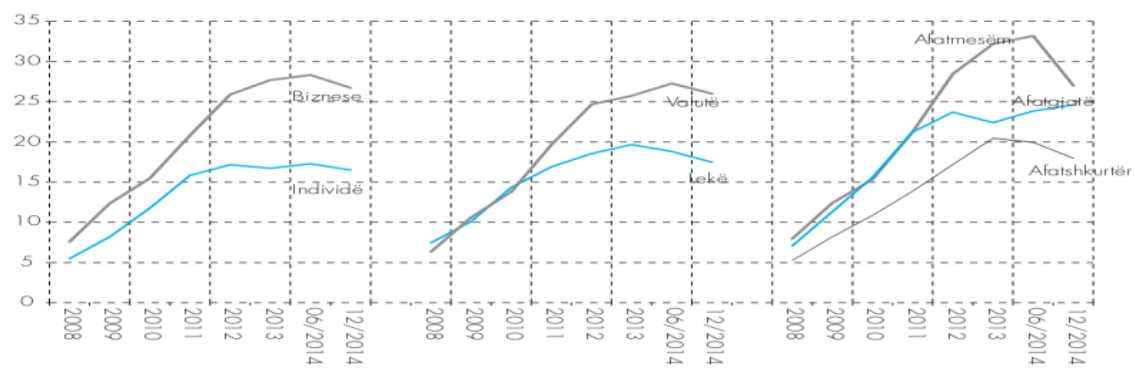

Source: Bank of Albania, 2015 
The above figure shows Albanian businesses are the main credit holders of the banking portfolio and the time holding the credit is medium-term, while the loans in foreign currency are higher than in the domestic currency. This may come as a result of trade and investment, where raw materials, machineries other investment products are ordered from foreign suppliers. Another reason may be that, the loans in foreign currency are with a lower interest rate, but with the high risk of exchange rate. However, the Bank of Albania has reduced steadily the interest rate, but the demand for loans still remains very low, because of uncertainty in the adoption and further changes on fiscal policies.

\section{6 Internet and e-trade}

Recent years, the Albanian society has been updated with the latest information technology. People are getting more literate toward the means of mass-communication, by exchanging messages specifically through the latest trend, internet. Nevertheless, there is a lack of legal framework about using e-trade and e-firms, which makes and e-trade to be quite difficult and safe.

\section{7 Technology and innovations}

In the course of years, schemes of installing and developing the business incubators have been applied, but they are not for a long time. There are two business incubators in Albania, one in Tirana and lately to Korca city, but still there is no industrial or technological park. The governments have started negotiations with foreign investors to open those incubators and technological parks, but up to now, everything is on paper. In order to increase the competitiveness of Albanians' SME$\mathrm{s}$, there should be undertaken a series of measures, starting from preparation of legal framework, establishing government institutions, compilation of action plans and activities to implement. Moreover, the domestic SME-s can increase competitiveness by innovative plans and technology transfer. This can occur by:

Developing an innovation strategy and technology transfer;

Developing and implementing programs, this will help to boost the competitiveness and internationalization of SME-S;

Supporting new businesses as a way to encourage and increase employment;

Creating innovative centers as an outcome from partnership programs;

Developing e-trade and creating a legal framework for e-trade and e-brand;

Establishing industrial areas;

The establishment of Euro Info Correspondence Center has helped the Albanian business to create better contacts with European Union and increasing trade cooperation.

\section{The governmental future strategies for the development of SME until 2017}

The Albanian governments have improved the strategies for growth, in order to achieve a positive business climate as soon as possible. A developed financial system and business climate can help the economy toward growth and stability. The government has some objectives, which need to be fulfilled by the end of 2017. These projects and objectives will be financed partially by the Albanian government and the remained part from foreign donators (IMF, WB). In this context, their development and performance, in the frame of market openness constitutes a real challenge. The long-term objectives for the development of SMEs aim to:

Increase the number of employed persons;

Increase the new enterprises;

Increase the crediting for the private sector; 
Gradually restrict the weight of informal sector.

Furthermore, strategic priorities for developing this sector consist of:

Harmonization of sector strategies, which affect the SME-s sector;

Providing transparency in decision-making, actions and measures, which affect the business environment;

Providing fair competition and supporting SME integration in international market;

Development of information technology and entrepreneurship culture.

Although, even the government has planned a development strategy, still there is room for changes and adoptions. The most important element of the Albanian development remains the rule of law and strong penalties for businesses and individuals who abuse with the law.

\section{Conclusion and recommendation}

A sustainable economic development of SME's sector can be achieved by increasing the number of new enterprises, improving productivity, and competing with international potentials. Hence, from the above discussion, we can conclude with some objectives, which can serve to further develop the above statement. These consist on:

\section{Motivating further positive attitudes and believes within the entrepreneurship}

This is one of the main concerns for long-term SME's development. In this point of view, it will be necessary to motivate the entrepreneurship to draw a strategy plan, which will have as a name introducing the entrepreneurship culture, formal and informal education with basic trainings for the entrepreneurs.

Improving and creating managing skills and training abilities

In many countries of the Region, it has been observed a lack of managing skills, which have a great impact on SMEs. Therefore, major steps toward entrepreneurship attitudes, should be taken since the first steps of education of new generations. Such steps will influence in building up a suitable environment for new entrepreneurs in education system, by making sure that young people are well informed about business culture as part of their education and future employment opportunities.

Entrepreneurship is considered as a basic concept in the long-term learning process. This process consists on various programs, which will encourage the entrepreneurship culture in every educational institution. Despite considering entrepreneurship promotion, media, of countries that aspire to become an EU member, should pay emphasis in entrepreneurship culture as well.

Increasing the working force qualification through:

Analyzing systematically the training programs;

Compiling entrepreneurship training programs;

Motivating creative entrepreneurship through:

Programs on creative entrepreneurship;

Studies for specific groups like women, youth, etc.

Developing businesses according to the European standards 
By taking in consideration the regional and European integration of Albania, the domestic SME's should be prepared for the challenges with other regional and European businesses as well. In order to face properly these challenges, SME's need to adopt innovative strategies and modern technologies. Moreover, those will need to:

Improve the business environment for further development of SME's;

Register the new businesses within a day, by creating networks in every Albanian district;

Standardize and unify the criteria and procedures for permissions, licenses, authorizations and certifications in every central and local authority;

Create a similar law to that of EU for Albanians SME's;

Create a counseling office for SME's

Facilitate the tax system for SMEs

Revise the tax payment system, in order to prevent corruption by introducing electronic payment;

Support SMEs development by boosting of institutional framework and public-private dialogue;

And finally,

To implement the European standards on production, on quality management systems, and on security management systems, such as EN, ISO, and trademarks.

\section{References}

Bank of Albania (2009) Economic Buletin, Vol. 12. No. 3. www. bankofalbania. org

Bank of Albania (2010) Statistical Raport, August, 2010. www. bankofalbania. org

Statistical Institute (2009) Anketa Strukturore e Ndermarrjeve ekonomike. www. instat. gov. al International Monetary Fund (2009) Regional Economic Outlook, October, 2009, www. imf. org

Ministry of Economy Trade and Energetic (2009) Strategic Development Program 2007-2009, www. mete. gov. al

Ministry of Economy and Trade (2015) Strategic Development Program 2015-2017 www. mete. gov. al

Ministry of Finance (2015) Economical data and reports, www. minfin. gov. al

World Bank (2016) Doing Business Report 2015-2016, www. worldbank. org 